\title{
AFFILIATE MOTIVATE WITH ADJUSTMENTS IN SCHOOL
}

\author{
MOTIF AFILIASI DENGAN PENYESUAIAN DIRI DI SEKOLAH \\ PADA REMAJA \\ Rismar Julia Utami', Cici Yulia ${ }^{2}$ \\ Program studi Bimbingan Konseling STKIP Muhammadiyah Sungai Penuh (Jambi), Univeristas Muhammadiyah Prof.DR. HAMKA \\ rismarjuliautami7@gmail.com, cicivulia@uhamka.ac.id
}

\begin{tabular}{ccc}
\hline Received: & Accepted: & Published: \\
25 Noveber 2021 & 27 November 2021 & 20 Januari 2022 \\
\hline
\end{tabular}

\begin{abstract}
ABSTRACK
This research is motivated by the lack of good and effective self-adjustment abilities in Muhammadiyah orphanage youths, which hinders social interaction when they are in the school environment and their affiliation motives become hampered. The purpose of this study was to determine the relationship between affiliation motives and adjustment in school for adolescents at the Putra Muhammadiyah Sungai Penuh Orphanage. This type of research is a correlational study with a population of 30 people. The sampling technique used in this research is saturated sampling, which means that the entire population is the sample. Based on the results of the Spearman Rank calculation, the correlation coefficient between affiliation motives and self-adjustment in school is $r=0.219$ with a significant level of 0.05 . From these results, it can be concluded that the affiliation motive is related to adjustment at school in adolescents, meaning that adolescents who have a high affiliation motive will make good adjustments when they are in their school environment. Thus, it is stated that there is a low and positive relationship between affiliation motives and adjustment in school for adolescents at the Putra Aisyiyah Orphanage in Sungai Penuh.
\end{abstract}

Keyword: Motive afilitiate, Self-adjustment

ABSTRAK

Penelitian ini dilatarbelakangi oleh kurangnya kemampuan penyesuaian diri pada remaja Panti Asuhan Muhammadiyah yang baik dan efektif sehingga menghambat pergaulan sosial ketika mereka berada di lingkungan sekolah dan motif afiliasi yang mereka milikipun menjadi terhambat. Tujuan dari penelitian ini adalah untuk mengetahui seajuahmana hubungan antara motif afiliasi dengan penyesuaian diri di sekolah pada remaja di Panti Asuhan Putra Muhammadiyah Sungai Penuh. Jenis penelitian ini adalah penelitian korelasional dengan jumlah populasi 30 orang. Teknik pengambilan sampel yang dilakukan dalam penelitian ini adalah dengan cara sampling jenuh, hal tersebut berarti keseluruhan populasi menjadi sampel. Berdasarkan hasil perhitungan Rank Spearman diperoleh hasil koefisien korelasi antara motif afiliasi dengan penyesuaian diri di sekolah sebesar $\mathrm{r}=0,219$ dengan taraf signifikan 0,05. Dari hasil tersebut bisa disimpulkan bahwa motif afiliasi berhubungan dengan penyesuaian diri di sekolah pada remaja, artinya remaja yang memiliki motif afiliasi yang tinggi akan melakukan penyesuaian diri yang baik ketika berada di lingkungan sekolahnya. Dengan demikian dinyatakan bahwa ada hubungan yang rendah dan positif antara motif afiliasi dengan penyesuaian diri di sekolah pada remaja di Panti Asuhan Putra Aisyiyah Sungai Penuh.

Kata Kunci : Motif Afiliasi, Penyesuaian Diri

This is an open access article distributed under the Creative Commons Attribution License, which permits unrestricted use, distribution, and reproduction in any medium, provided the original work is properly cited. (C2019 by author.

\section{PENDAHULUAN}

Remaja merupakan sosok yang penuh potensi namun perlu bimbingan agar dapat mengembangkan apa yang telah dimilikinya untuk kemajuan bangsa dan negara. Secara umum dapat dikatakan bahwa sikap remaja saat ini masih berada dalam tahap mencari jati diri. Identitas diri yang dicari remaja berusaha untuk menjelaskan siapa dirinya dan apa perannya didalam masyarakat, sehingga mereka berupaya untuk 
menentukan sikap dalam mencapai kedewasaan (Hurlock, 2000).

Kenyataannya saat ini tidak semua remaja yang diharapkan kelak menjadi ekonomi, ditinggal oleh orang tua karena meninggal atau permasalahan keluarga sehingga menyebabkan remaja mengalami permasalahan-permasalahan sosial (Ali dan Asrori, 2006). Remaja yang berada di panti asuhan merupakan remaja yang kurang beruntung, karena mereka tidak lagi mempunyai orang tua maupun keluarga yang bisa mereka jadikan sebagai tempat bersandar dan tempat untuk mengeluhkan segala kesulitan hidup.

Mereka dibesarkan di sebuah tempat dimana mereka harus saling berbagi dengan remaja lain yang juga memiliki nasib yang sama yakni di Panti Asuhan Aisyiyah Sungai Penuh yang disediakan oleh yayasan Muhammadiyah, hal ini menjadikan mereka berbeda dari remaja-remaja lain dimana terlihat dari keterbatasan fasilitas yang mereka miliki.

Penyesuaian diri yang baik dan efektif harus dimiliki oleh setiap orang termasuk remaja yang berada di Panti Asuhan Putra Aisyiyah Sungai Penuh. Menurut Ali dan Asrori (2006) kemampuan melaksanakan penyesuaian diri yang baik dan efektif memberikan peluang bagi mereka untuk eksistensi diri dalam kehidupan sosialnya. Namun pada kenyataannya, ada beberapa hal yang menghambat penyesuaian diri pada remaja di Panti Asuhan Putra Aisyiyah Sungai Penuh generasi penerus bangsa dapat menikmati kehidupannya. Hal ini bisa disebabkan oleh beberapa faktor diantaranya faktor

ini ketika mereka berada di lingkungan sekolah. Remaja yang berada di Panti Asuhan ini tidak bersekolah di satu tempat saja melainkan mereka terpencar di beberapa sekolah. Pada saat remaja di Panti Asuhan ini berada di sekolah otomatis mereka akan berbaur dengan anak-anak lain di sekolah mereka, sehingga remaja yang ada di Panti Asuhan Aisyiyah Sungai Penuh ini kurang mampu dalam menyesuaikan diri dengan lingkungan sekolahnya.

Ada beberapa faktor yang menyebabkan mereka kesulitan dalam menyesuaikan diri dengan lingkungan sekolah, mereka menganggap diri mereka memiliki keterbatasan kemampuan untuk dapat aktif dalam kegiatan yang dilakukan sekolah tersebut.

Remaja di Panti Asuhan ini juga mengatakan bahwa mereka lebih leluasa untuk berpendapat ketika berada di Panti Asuhan daripada ketika mereka berada di lingkungan sekolah. Dengan demikian, motif afiliasi yang dimiliki oleh remaja yang ada di Panti Asuhan Aisyiyah ini menjadi terhambat. Schneiders (2003) mengatakan bahwa penyesuaian diri yang baik akan terjadi apabila individu dapat menanggulangi kebutuhan-kebutuhan dalam diri, termasuk kebutuhan afiliasi.METODE PENELITIAN 
Jenis penelitian yang digunakan dalam penelitian ini adalah korelasional. Penelitian korelasional merupakan salah satu bentuk rancangan penelitian yang bertujuan untuk mencari hubungan antara satu variabel dengan variabel lainnya, dengan cara mengukur setiap variabel tersebut, untuk memperjelas hubungan antara variabel yang diteliti, maka akan dilakukan perhitungan-perhitungan dengan bantuan metode statistik (Arikunto, 2002). Populasi pada penelitian ini adalah Remaja yang ada di Panti Asuhan Muhammadyah Padang yang berjumlah $\mathrm{N}=30$ orang. Teknik pengambilan sampel yang dilakukan dalam penelitian ini adalah dengan cara sampling jenuh.

Menurut Sugiyono (2006), sampling jenuh/total samling adalah teknik pengambilan sampel bila semua anggota populasi digunakan sebagai sampel. Hal ini dilakukan karena populasi relatif kecil, kurang lebih 30 orang. Jadi keseluruhan dari populasi digunakan dalam penelitian ini, maka $\mathrm{N}=30$ orang. Teknik pengumpulan data yang digunakan adalah model skala likert, yaitu suatu metode pernyataan sikap yang menggunakan respon subjek sebagai dasar penentu skalanya. Dalam penelitian ini untuk mengungkapkan aspek motif afiliasi, penulis menggunakan skala yang dibuat sendiri dengan menggunakan teori dari MC.Clelland, sedangkan dalam mengungkap aspek penyesuaian diri penulis menggunakan skala yang dibuat sendiri dengan menggunakan teori dari Schneiders.
Pengolahan data dalam penelitian ini dilakukan dengan menggunakan uji korelasi Rank Spearman.

\section{HASIL DAN PEMBAHASAN}

Berdasarkan hasil pehitungan Rank Spearman diperoleh hasil koefisien korelasi antara motif afiliasi dengan penyesuaian diri di sekolah sebesar $r=0,219$ dengan taraf signifikan 0,05. Hal tersebut menunjukkan bahwa "ada hubungan antara motif afiliasi dengan penyesuaian diri di sekolah pada remaja di Panti Asuhan Putra Aisyiyah Sungai Penuh", berdasarkan kategori Guilford (dalam Sugiyono, 2006) korelasi ini menunjukkan korelasi yang rendah, artinya remaja yang ada di Panti Asuhan Putra Aisyiyah Sungai Penuh memiliki motif afiliasi yang rendah dan mereka juga kurang mampu dalam melakukan penyesuaian diri yang baik ketika berada di sekolah.

Kekuatan korelasi yang diperoleh dalam hasil perhitungan korelasi antara motif afiliasi dengan penyesuaian diri di sekolah adalah sebesar 0,219. Derajat rendah ini dalam suatu korelasi positif menunjukkan adanya penyimpangan dari kecenderungan data yang diperoleh pada remaja di Panti Asuhan Putra Aisyiyah Sungai Penuh terdapat 5 orang yang memiliki motif afiliasi yang tinggi dan mereka juga tidak dapat melakukan penyesuaian diri yang baik ketika berada di sekolah, artinya motif afiliasi tidak mampu memberikan pengaruh terhadap kemampuan individu dalam melakukan 
penyesuaian diri di sekolah. Penyesuaian diri di sekolah yang dilakukan oleh remaja akan menjadi lebih baik jika seseorang remaja tersebut memiliki motif afiliasi yang tinggi, hal ini sejalan dengan teori yang dikatakan oleh Schneiders (2003) bahwa motif merupakan kata kunci dalam penyesuaian diri.

Menurut Hurlock (2000), salah satu tugas perkembangan masa remaja yang tersulit adalah yang berhubungan dengan penyesuaian sosial. Remaja harus menyesuaikan diri dengan lawan jenis dalam hubungan yang belum pernah ada dan harus menyesuaikan dengan orang dewasa di luar lingkungan keluarga dan sekolah. Selanjutnya Mc. Clelland dalam Ali dan Asrori (2006) menyatakan bahwa motif afiliasi adalah kebutuhan nyata dari manusia. Kebutuhan afiliasi umumnya tercermin pada situasi yang bersahabat dalam interaksi dengan orang lain. Kebutuhan afiliasi biasanya terpenuhi ketika individu mampu bekerja sama dengan orang lain, menunjukkan performa lebih baik ketika insentif afiliatif tersedia, memelihara hubungan interpersonal, memiliki perilaku kepemimpinan, menghindari persaingan dan adanya rasa takut akan penolakan.

Dari hasil uji korelasi Rank Spearman antara aspek-aspek motif afiliasi dengan penyesuaian diri di sekolah pada remaja Panti Asuhan Putra Aisyiyah Sungai Penuh didapatkan hasil pada aspek pertama yaitu menunjukkan performa lebih baik ketika insentif afiliatif tersedia yang memiliki koefisien korelasi sebesar 0,170. Hal ini menunjukkan bahwa ada korelasi yang lemah dan bisa diabaikan, sehingga bisa disimpulkan bahwa aspek menunjukkan performa lebih baik ketika insentif afiliatif tersedia belum tentu mempengaruhi penyesuaian diri remaja ketika berada di lingkungan sekolah.

Hal ini disebakan karena adanya faktor-faktor lain yang mempengaruhi penyesuaian diri remaja seperti kondisi fisik yang diungkapkan oleh Schneiders (2003). Kondisi fisik yang sehat dapat menimbulkan penerimaan diri, percaya diri, harga diri dan lain-lain yang akan menjadi kondisi yang sangat mempengaruhi bagi proses penyesuaian diri. Sebaliknya, kondisi yang tidak sehat dapat menyebabkan perasaan rendah diri, kurang percaya diri bahkan menyalahkan diri sehingga akan berpengaruh kurang baik bagi proses penyesuaian diri.

Aspek kedua yaitu memelihara hubungan interpesonal yang dihubungkan dengan penyesuaian diri di sekolah didapat koefisien korelasi sebesar 0,173. Hal ini menunjukkan bahwa ada korelasi yang lemah dan bisa diabaikan, sehingga bisa disimpulkan bahwa aspek memelihara hubungan interpersonal belum tentu mempengaruhi penyesuaian diri remaja ketika berada di lingkungan sekolah. Hal ini disebakan karena adanya faktor-faktor lain yang mempengaruhi penyesuaian diri remaja seperti kepribadian yang diungkapkan oleh Schneiders (2003). 
Kemauan dan kemampuan untuk berubah merupakan karakteristik kepribadian yang akan mempengaruhi proses penyesuaian diri. Kemauan dan kemampuan untuk berubah ini akan berkembang melalui proses belajar bagi individu yang dengan sungguh-sungguh belaja untuk dapat berubah, maka kemampuan menyesuaikan dirinya akan berkembang juga. Sebaliknya, kualitas kemampuan untuk berubah akan berkurang tau menurun disebabkan oleh sikap dan kebiasaan yang kaku, sering mengalami kecemasan dan frustasi.

Aspek ketiga yaitu bekerja sama dengan orang lain yang dihubungkan dengan penyesuaian diri di sekolah didapat koefisien korelasi sebesar 0,299. Hal ini menunjukkan bahwa ada korelasi yang bertaraf rendah, artinya Hurlock (2000) kecenderungan remaja untuk membentuk pertemanan, bersosialisasi dan berinteraksi secara dekat dan bekerja sama dengan orang lain akan mempengaruhi penyesuaian diri yang baik. Pada aspek keempat yaitu perilaku kepemimpinan yang dihubungkan dengan penyesuaian diri di sekolah didapat koefisien korelasi sebesar 0,180. Hal ini menunjukkan bahwa ada korelasi yang lemah dan bisa diabaikan, sehingga bisa disimpulkan bahwa aspek perilaku kepemimpinan belum tentu mempengaruhi penyesuaian diri remaja ketika berada di lingkungan sekolah. Schneiders (2003) menyatakan ada faktor lain yang mempengaruhi penyesuaian diri individu yaitu lingkungan keluarga, Semua konflik dan tekanan yang ada dapat dihindarkan atau dipecahkan bila individu dibesarkan dalam keluarga dimana terdapat keamanan, cinta, respek, toleransi dan kehangatan. Dengan demikian penyesuaian diri akan menjadi lebih baik bila dalam keluarga individu merasakan bahwa kehidupannya berarti.

Aspek kelima yaitu menghindari persaingan yang dihubungkan dengan penyesuaian diri di sekolah didapat koefisien korelasi sebesar 0,145. Hal ini menunjukkan bahwa ada korelasi yang lemah dan bisa diabaikan, sehingga bisa disimpulkan bahwa aspek menghindari persaingan belum tentu mempengaruhi penyesuaian diri remaja ketika berada di lingkungan sekolah. Hal ini disebakan karena adanya faktor-faktor lain yang mempengaruhi penyesuaian diri remaja seperti proses belajar yang diungkapkan oleh Schneiders (2003).

Kemampuan belajar merupakan unsur penting dalam penyesuaian diri individu karena respon-respon dan sifat-sifat kepibadian yang diperlukan bagi proses penyesuaian diri diperoleh dan diserap melalui proses belajar. Kemampuan belajar akan muncul dari dalam diri individu. Oleh sebab itu perbedaan pola-pola penyesuaian diri dari yang normal sampai dengan yang tidak normal merupakan hasil perubahan yang dipengaruhi oleh proses belajar dan kematangan. Pengaruh proses belajar akan muncul dalam bentuk mencoba-coba dan gagal (trial and error), pengondisian (conditioning), dan menguhubungkan (association) berbagai 
faktor yang ada dimana individu itu melakukan proses penyesuaian diri.

aspek terakhir yaitu rasa takut akan penolakan yang dihubungkan dengan penyesuaian diri di sekolah didapat koefisien korelasi sebesar 0,221. Hal ini menunjukkan korelasi yang bertaraf rendah, artinya remaja yang merasa takut ditolak oleh anggota kelompok lain mencoba untuk dapat mengikuti apa yang diinginkan oleh anggota kelompok lainnya. Sehingga hal ini membuat mereka tidak dapat menyampaikan apa yang mereka inginkan, Mc Clelland (dalam Ali dan Asrori, 2006) mengatakan bahwa rasa takut akan penolakan ini di perlihatkan dengan adanya sikap konformitas dan bersikap sebagai pengikut.

Setiap remaja yang ada di Panti Asuhan Putra Aisyiyah Sungai Penuh tidak memiliki kemampuan yang sama dalam membentuk suatu hubungan dengan orang lain. Kenyataannya ada beberapa remaja yang masih sulit dalam penyesuaian diri di sekolah. Dilihat dari persentase motif afiliasi pada remaja di Panti Asuhan Putra Aisyiyah Sungai Penuh terdapat $70 \%$ dari jumlah subjek penelitian sangat merasakan bahwa motif afiliasi dapat mempengaruhi penyesuaian diri di sekolah pada remaja. 13,3 \% dari subjek penelitian tidak merasakan bahwa motif afiliasi tidak memberikan pengaruh pada penyesuaian diri di sekolah. 16,6\% dari subjek penelitian sangat merasakan bahwa kebutuhan untuk berhubungan dengan orang lain sangat mempengaruhi penyesuaian diri di sekolah pada remaja. Jika seseorang memiliki motif afiliasi yang tinggi maka mereka akan lebih mudah dalam menyesuaikan diri di sekolah namun hal ini tidak signifikan.

Dilihat dari persentase penyesuaian diri di sekolah pada remaja Panti Asuhan Muhammadiyah Cabang Pauh Padang terdapat $86,66 \%$ siswa yang melakukan penyesuaian diri cukup baik dalam menjalin hubungan dengan orang lain. 6,66 \% dari subjek penelitian kurang dapat melakukan penyesuaian diri di sekolah yang kurang baik. $6,66 \%$ dari subjek penelitian melakukan penyesuaian diri di sekolah yang baik sehingga mereka dapat membina hubungan dengan orang lain dengan baik pula. Besar sumbangan dari variabel motif afiliasi terhadap penyesuaian diri di sekolah yang dilakukan oleh remaja Panti Asuhan Muhammadiyah Cabang Pauh Padang adalah $5 \%$, sedangkan 95,5 \% lagi dipengaruhi oleh faktor-faktor lain. Faktor lain yang dapat mempengaruhi penyesuaian diri di sekolah pada remaja menurut Schneiders (2003) adalah kepribadian, kondisi fisik, proses belajar, lingkungan serta agama dan budaya.

\section{KESIMPULAN}

Berdasarkan dari hasil analisis dan pembahasan yang dilakukan sebelumnya, maka dapat ditarik kesimpulan yang sekaligus merupakan jawaban dari tujuan penelitian. Dengan menggunakan teknik perhitungan Rank Spearman, maka diperoleh hasil koefisien korelasi antara motif afiliasi dengan penyesuaian diri di sekolah sebesar $r=0,219$ 
dengan taraf signifikan 0,05 yang menyatakan bahwa terdapat hubungan yang kurang signifikan atau lemah antara motif afiliasi dengan penyesuaian diri di sekolah pada remaja Panti Asuhan Muhammadiyah Cabang Pauh Padang. Dari hasil tersebut bisa disimpulkan bahwa motif afiliasi berhubungan dengan penyesuaian diri di sekolah pada remaja, artinya remaja yang memiliki motif afiliasi yang tinggi akan melakukan penyesuaian diri yang baik ketika berada di lingkungan sekolahnya. Dengan demikian dinyatakan bahwa ada hubungan yang rendah dan positif antara motif afiliasi dengan penyesuaian diri di sekolah pada remaja Panti Asuhan Muhammadiyah Cabang Pauh Padang. Dari penelitian yang telah dilakukan, maka penulis dapat menyampaikan beberapa saran yang dapat diambil sebagai pertimbangan yang diharapkan dapat bermanfaat bagi Panti Asuhan Putra Aisyiyah Sungai Penuh, antara lain sebagai berikut :

1. Bagi remaja di Panti Asuhan Putra Aisyiyah Sungai Penuh: Agar mau melibatkan diri pada kegiatankegiatan yang diadakan di lingkungan sekolah serta adanya keinginan untuk aktif dalam aktivitas tersebut. Sebaiknya remaja di Panti Asuhan Putra Aisyiyah Sungai Penuh dapat membentuk suatu hubungan yang baik dengan orang lain dan dapat melakukan penyesuaian diri yang baik ketika berada di lingkungan sekolah.

2. Bagi para pengurus yayasan Panti Asuhan Putra Aisyiyah Sungai Penuh agar dapat membantu remaja yang ada Panti dalam mengembangkan motif afiliasinya sehingga tercapai penyesuaian diri yang baik pula.

\section{UCAPAN TERIMAKASIH}

Terima kasih atas dukungan Kepala Yayasan Panti Asuhan Aisyiyah Putra Sungai penuh Jambi yang memberikan arahan dan masukan dalam kemajuan konten ini, lembaga lemlit universitas muhammadiyah Prof.DR HAMKA yang telah memberikan dukungan baik secara

\section{DAFTAR PUSTAKA}

Ali dan Asrori. 2005. Psikologi Remaja; Perkembangan Peserta Didik. Bandung: PT. Remaja Rosdakarya

Hurlock B. Elizabeth. 2000. Perkembangan Anak. Ciracas, Jakarta: Penerbit Erlangga.

Schneiders. 2003. Adolescence. Terjemahan: Adelar, S.B., Saragih, S. Jakarta: Erlangga.

Sugiyono. 2006. Metode Penelitian Pendidikan. Bandung : Alfabeta.

Suharsini, Arikunto. 2002. Prosedur Penelitian; Suatu Pendekatan Praktik. Edisi Revisi. Jakarta: PT. Rineka Cipta. 